\title{
A arte da autoinvenção no romance Nove Noites*
}

\author{
The art of self-invention in the Nove Noites novel
}

\author{
Joanita Baú de Oliveira \\ Doutoranda do Programa de Pós-graduação em Letras da \\ Universidade Federal de Pernambuco \\ joanita.bau@outlook.com
}

Resumo: $O$ presente trabalho investiga as relações entre o factual e o fictício no romance Nove Noites, de Benardo Carvalho. O objetivo é elucidar como a subjetividade dos personagens é construída a partir da simbiose entre fatos reais e inventados. Analisa-se também como as classificações genéricas entre narrativa literária e narrativa científica (seja historiográfica, antropológica ou jornalística) são problematizadas pela forma como informações verídicas e relato fictício se relacionam na construção dessa obra romanesca. Para tanto, a análise ocorre em três níveis: a trajetória dos protagonistas, o processo de elaboração e a metaficção proposta pela obra romanesca e, por fim, a transformação de pessoas reais em narradores fictícios. Ao final da pesquisa, constata-se que, nestas três instâncias, as semelhanças e as diferenças, as verdades e as ilusões são conjugadas na construção da imagem que os sujeitos constroem para se mostrar ao mundo.

Palavras-chave: Subjetividade, Factual, Fictício.

\begin{abstract}
The present work investigates the relations between the factual and the fictitious in the novel Nove Noites, de Bernardo Carvalho. The objective is to elucidate how the subjectivity of the characters is constructed from the symbiosis between real and invented facts. It is also analyzed how the generic classifications between literary narrative and scientific narrative (be it historiographical, anthropological or journalistic) are problematized by the way that veridical information and fictitious narrative are related in the construction of this romanesque work. For this, the analysis takes place in three levels: the trajectory of the protagonists, the process of elaboration and the metafiction proposed by the romanesque work, and, finally, the transformation of real people into fictional narrators. At the end of the research, it is observed that, in these three instances, similarities and differences, truths and illusions are combined in the construction of the image that the subjects construct to show themselves to the world.
\end{abstract}

Keywords: Subjectivity, Factual, Fictitious

*O presente trabalho foi realizado com apoio do CNPq, Conselho Nacional de Desenvolvimento Científico e Tecnológico-Brasil. 


\section{Introdução}

Nove Noites, de Bernardo Carvalho, narra a investigação realizada por um jornalista brasileiro sobre os motivos que levaram o antropólogo americano Buell Quain a suicidar-se durante sua passagem pelo Brasil. Construído a partir de uma intrincada reunião de fatos reais e ficção, o romance é composto por dois relatos. Em um dos fluxos, é contado o processo de pesquisa empreendido pelo jornalista. No outro, têm-se uma carta-testamento deixada por Manuel Perna, amigo do etnólogo, a um destinatário desconhecido. A partir desses dois planos, surgem várias camadas que se desdobram umas sobre as outras. Através delas, tomamos conhecimento da história de Buell Quain, da vida do jornalista, do percurso que este percorre para investigar o suicídio e, por fim, dos percalços que levaram à construção do romance.

O lastro de fatos verídicos se faz sentir ao longo de todo o livro. Ele apresenta dados históricos, reconstituídos através de cartas e outros documentos oficiais. Além disso, a existência de parte de seus personagens pode ser comprovada e as memórias de infâncias do narrador coincidem com as do autor. Não obstante, as investigações que precederam a escrita do livro e são relatadas ao longo da própria narrativa, de fato, aconteceram. Assim, à medida que está ancorado em dados externos, sendo que alguns deles, inclusive, dizem respeito à biografia do escritor, a trama lembra o romance histórico e autoficcional.

A busca por uma verdade, entretanto, é frustrada. Imerso em um labirinto de pistas, que não chegam a fornecer nenhuma informação concreta que possa levar à solução do mistério, o narrador decide transformar a pesquisa empreendida em romance. Trata-se, portanto, de um romance metaficcional, uma vez que o processo de sua construção é deslindado dentro dele mesmo. Como toda narrativa dessa natureza, ele não esconde seu caráter ilusionista, ao contrário, faz questão de revelá-lo. Assim, as fronteiras entre realidade e ficção e as classificações genéricas são problematizadas pela forma romanesca empreendida por Bernardo Carvalho.

O conflito entre dado empírico e ilusão também perpassa a vida dos personagens. Há em Buell Quain um mistério que precisa ser encoberto. Não obstante, o momento político em que esse personagem viveu exigia cautela na expressão de julgamentos e ideias, em especial de estrangeiros residentes no Brasil. Do mesmo modo, o narrador, em vários momentos, precisa fingir para obter informações e alcançar seus 
objetivos. Portanto, em ambos os casos, identidades precisam ser forjadas como meio de negociação com o diferente.

Nesse sentido, o presente trabalho interroga como a mescla entre o factual e o fictício, que caracteriza Nove Noites, impacta nas representações do Eu e o Outro e nas relações que eles estabelecem entre si.

Para responder estas perguntas, o presente trabalho seguiu três vieses. Primeiro, comparamos os percursos de Buell Quain e do narrador-jornalista, a fim de registrar como cada um constrói identidades e alteridades. Em seguida, analisamos a mestiçagem de gênero na forma romanesca, para compreender qual o sentido do contraponto traçado entre narrativa literária e narrativa científica. Finalmente, procuramos deslindar a composição dos narradores, no intuito de aclarar como se deu o processo de ficcionalização do Eu e do Outro.

\section{Nuances de realidade e ficção em Nove Noites Dos personagens: a busca do Outro como encontro do si}

A trajetória de Buell Quain assemelha-se a do herói dramático. Sua busca pelo Outro é movida pela tentativa de reverter o destino, neutralizando a marca que o assiná-la. Entretanto, durante o percurso, a quebra dos tabus, movido pela hybris, torna-se inevitável, assegurando o final trágico. No momento em que o narrador relata os fatos relacionados ao nascimento de Quain, sua voz lembra o oráculo grego, prenunciando a futura desgraça:

O mais incrível, nos nascimentos, é a euforia cega com que os pais encobrem o risco e a imponderabilidade do que acabam de criar, a esperança com que o recebem e que os faz transformar em augúrio promissor a incapacidade de prever o futuro que ali se anuncia e a impotência de todas as medidas de precaução nesse sentido. Se assim não fosse, é bem provável que o ser humano já tivesse se extinguido da face da Terra pelas mãos de mães zelosas e assassinas (CARVALHO, 2006: 16).

Em vários outros momentos do enredo a semelhança com a tragédia é acentuada. Buell Quain parecia ser portador de uma característica que, inevitavelmente, o levaria ao suicídio. Entre os vários trechos que denotam uma marca diferenciadora ou o traço que destoa dos padrões sociais vigentes, destacaremos aqueles que nos pareceram mais 
relevantes. O primeiro deles refere-se ao momento em que Manoel Perna percebe algo marcante na personalidade do antropólogo:

Desde o início, embora não pudesse prever a tragédia, fui o único a ver nos olhos dele o desespero que tentava dissimular mais nem sempre conseguia, e cuja razão, que cheguei a intuir antes mesmo que ela me fosse revelada, preferi ignorar, ou fingir que ignorava, nem que fosse só para aliviá-lo. [...] Assim são os homens. Ou você acha que quando nos olhamos não reconhecemos no próximo o que em nós mesmo tentamos esconder? (CARVALHO, 2006: 8).

O fato de Quain ser um dos alunos diletos de Ruth Benedict, antropóloga americana, também é apontado como sintomático de algum sinal diferenciador: "Depoimentos de alunos e colegas atribuem a Benedict uma preferência por estudantes em desacordo com o mundo a que pertenciam e de alguma forma desajustados em relação ao padrão da cultura americana. É possível que reconhecesse neles algo de si mesma, e os protegesse" (CARVALHO, 2006: 15).

A ligação de Quain com Ruth Benedict também ajuda a explicar a sua busca pelo diverso. Segundo o narrador, Benedict pertencia à "corrente antropológica que ficou conhecida por associar Cultura e Personalidade, na tentativa de explicar o comportamento pela inserção social e assim relativizar os conceitos de normalidade e anormalidade no que diz respeito aos indivíduos" (CARVALHO, 2006: 14). Como sua orientadora, Buell também procurava na cultura do Outro uma maneira de converter as regras sociais que o excluíam. Sobre este ponto, é interessante observar o seguinte trecho da carta-testamento de Manoel Perna: "mas seria demais lhe dizer que o dr. Buell, meu amigo, bebeu comigo e me contou que procurava entre os índios as leis que mostrariam ao mesmo tempo o quanto as nossas são descabidas e um mundo no qual por fim ele coubesse? Um mundo que o abrigasse?" (CARVALHO, 2006: 42).

Assim, a escolha de Buell pela antropologia foi suscitada pela tentativa de reverter a "falha trágica". Ainda segundo a mesma carta, essa decisão foi tomada, provavelmente, após Quain identificar-se com a trama de um filme que contava a história de um amor proibido:

Não fazia ideia do filme a que assistiria quando entrou no cinema, assim como não fazia ideia do destino que ali lhe era apresentado. Assistiu vidrado 
a uma história de amor no Pacífico Sul. A um amor proibido pelas leis de uma sociedade de nativos. Um amor condenado pelos deuses. Um tabu. Até a noite em que me contou suas lembranças, não sabia o quanto havia do efeito daquele amor proibido na própria vocação. Ao sair do cinema, lembrava-se apenas dos corpos dos nativos delineados pelo sol e pela água, as gotas de prata, como pérolas, nos corpos refletidos de sol contra o céu. Iria ao encontro deles. Saiu do cinema determinado (CARVALHO, 2006: 42).

O sonho de conhecer os habitantes do Pacífico Sul é realizado quando Buell é aceito no departamento de Pós-graduação em Antropologia de Colúmbia. Isso permitiu que o antropólogo efetuasse, em uma das aldeias de Vanua Levu, nas ilhas Figi, seu primeiro trabalho de pesquisa de campo. De acordo com Manuel Perna, entre esses nativos, o jovem americano encontrara o paraíso:

Na primeira noite ele me falou de uma ilha no pacífico, onde os índios são negros. Me falou do tempo que passou entre esses índios e de uma aldeia, que chamou Nakoroka, onde cada um decide o que quer ser, pode escolher sua irmã, seu primo, sua família, e também sua casta, seu lugar em relação aos outros. Uma sociedade muito rígida nas suas leis e nas suas regras, onde, no entanto, cabe aos indivíduos escolher os seus papéis. Uma aldeia onde a um estranho é impossível reconhecer os traços genealógicos, as famílias de sangue, já que os parentes são eletivos, assim como as identidades. O paraíso, o sonho de aventura do menino antropólogo (CARVALHO, 2006: $41)$.

Esses dois fragmentos são cruciais para compreensão de como o traço diferenciador que marcava Quain atua no desfecho da história. A relação entre eles pode ser mais bem compreendida através do livro Totem e Tabu, de Sigmund Freud (1980). O psicanalista relata que o tabu, normalmente, se liga a um aspecto sagrado. Trata-se de uma proibição que visa manter uma ordem social. Sua quebra implica a profanação e uma consequente punição. $\mathrm{O}$ tabu investigado por Freud está relacionado ao estabelecimento de regras para normatizar as relações sexuais. Ele esclarece que em certas tribos as relações de parentesco são estabelecidas através do Totem, espécie animal ou vegetal que simboliza cada clã. Os indivíduos que se filiam ao mesmo Totem, 
não podem manter relações sexuais entre si. Assim, a proibição visa impedir uniões endogâmicas.

No caso de Nove Noites, o tabu quebrado está ligado a um amor proibido pelas convenções sociais, como no filme que Buell assistiu. O jovem antropólogo teve um relacionamento com um fotógrafo americano e uma amiga. Nas cartas que recebeu pouco antes do suicídio, Buell descobriu que sua amiga e o fotógrafo também mantinham um caso. Daí se depreende que o traço de personalidade que o antropólogo precisava esconder era a homossexualidade ou bissexualidade, os quais são considerados tabu dentro de uma sociedade heteronormativa. Já o desejo de Quain escolher seus próprios familiares, como acontecia entre os habitantes de Vanua Levu, se relaciona ao desejo de poder escolher livremente sua identidade. Talvez isto também esteja ligado à vontade de tornar o fotógrafo e sua amiga parentes, pela amizade que mantinham com ele, e assim evitar que se tornassem amantes.

A homossexualidade de Quain não podia ser vivida livremente. A repressão suscitou nele a sensação de estar sendo espionado o tempo todo. No Brasil, a sensação de vigilância aumentou. Na época, o Estado Novo mantinha um rígido controle, especialmente sobre os estrangeiros. Assim, era necessário que Buell se escondesse atrás de máscaras. Em vários outros trechos do romance se torna claro que Quain não estava satisfeito com as características e a personalidade dos índios brasileiros, os quais ele deprecia traçando comparações com os habitantes do Pacífico Sul. Ele se recusava a participar da vida da tribo. Recusava-se a ser um índio. Entretanto, para os órgãos do governo do Brasil, ele esconde-se atrás da figura do antropólogo capaz de adaptar-se a qualquer situação. Isso se torna claro nas cartas que enviou à Maria Júlia Pourchet, uma das responsáveis pelas pesquisas no país, e à Ruth Landes, amiga pessoal, a respeito de suas impressões sobre a cidade de Carolina e os índios. Na primeira há elogios, na segunda, críticas e sarcasmo.

É por esse clima de controle repressivo que Manuel Perna decide ocultar uma das cartas escritas por Quain pouco antes do suicídio. Perna tinha medo que a missiva, ao revelar a homossexualidade do antropólogo, tornaria "os índios suspeitos de um crime presumido de vingança ou autodefesa" (CARVALHO, 2006: 41).

Entretanto, o texto dá margem para supormos que a repressão do Estado Novo teve consequências ainda mais graves. A intolerância seria um dos motivos que levaram ao suicídio de Quain, ao agravar sua mania de perseguição. Em vários momentos, o antropólogo repete: “Todo suicídio é assassínio". Manoel Perna também desconfia que 
"ele se adiantara ao assassinato, que não quis deixar nenhuma chance ao destino" (CARVALHO, 2006: 41). Além disso, quando bebia, Buell também falava que estava sendo vigiado:

Achava que estivessem atrás dele, que aonde fosse eles o encontrariam. Não via saídas. Eu perguntava, mas ele não me dizia quem eram eles. Me contou que tinha vivido sob vigilância no Rio de Janeiro. Queria dizer que era vigiado onde quer que estivesse. Sabiam de tudo o que fazia, por mais que se escondesse, por mais que agisse em segredo, por mais que não contasse nada a ninguém (CARVALHO, 2006: 99).

A paranoia do antropólogo encontrou eco no estado de medo vivenciado pelos Trumai, primeiro grupo indígena que ele pesquisou quando chegou ao Brasil. De acordo com Manoel Perna, nos Trumai, Buell "tinha encontrado um povo cuja cultura era a representação coletiva do desespero que ele próprio vivia como um traço de personalidade" (CARVALHO, 2006: 51). Assim como Quain, os Trumai viviam uma vida atormentada. Eles estavam reduzidos a um número pequeno e eram constantemente ameaçados pelas tribos vizinhas. O terror em que viviam, fazia-os ver na morte uma liberação para o sofrimento. Nas entrelinhas do texto, depreende-se que, mais do que identificar a sua agonia com a dos referidos índios, Quain aprendeu com eles um possível modo de libertação.

Antes de optar pelo suicídio, Quain tentou reverter sua "falha trágica". A busca por culturas diferentes, pelo(s) seu(s) Outro, pode ser compreendida como busca por uma lei que convertesse o tabu ligado à homossexualidade em noa, isto é, livre de impedimentos, ou, ao menos, busca por um lugar onde pudesse viver sem máscaras. Enquanto isso, precisou ocultar-se. "Ele sempre viveu essa obsessão: não parecer e na realidade ser" (CARVALHO, 2006: 32), disse Castro Farias em entrevista ao Narrador. Embora Farias estivesse se referindo apenas à condição financeira abastada do antropólogo, pode-se usar essa frase para representar toda a vida de Buell. Durante sua trajetória, precisou ficcionalizar a própria identidade. A ambiguidade de sua personalidade pode ser depreendida pelas informações contraditórias de suas cartas, ou mesmo pelo modo metafórico utilizado para revelar seu segredo a Manoel Perna: através da narração de uma lenda do Pacífico Sul. Na angústia da dúvida entre ser e não-ser, decidiu-se por cumprir o fado trágico através do suicídio. 
Se a trajetória de Quain assemelha-se a do herói da tragédia, a do narrador do romance Nove Noites pode ser comparada a do herói épico. Trata-se de alguém predestinado a cumprir uma missão de extrema dificuldade, devendo, portanto, passar por muitas provas e superar os próprios limites. No caso do romance aqui analisado, o herói, isto é, o narrador-jornalista, terá como missão desvendar os motivos do suicídio de Buell Quain. Entre as provas que deverá cumprir para chegar ao objetivo, destaca-se a necessidade de conjugar identidades e alteridades no limiar entre realidade e ficção. Portanto, assim como ocorre com o antropólogo, o narrador-jornalista necessitará, em muitos momentos, ficcionalizar-se.

A predestinação do narrador ocorreu enquanto cuidava do pai hospitalizado. Certa noite, o paciente ao lado chamou o jornalista de Bill Cohen. Anos mais tarde, ao ler um artigo no qual o caso de Buell Quain fora citado, o narrador relacionou os dois nomes. Esses dois motivaram uma busca sem tréguas para descobrir os motivos do suicídio do antropólogo, que culminaram na escrita do romance:

Àquela altura dos acontecimentos, depois de meses lidando com papéis de arquivos, livros e anotações de gente que não existia, eu precisa ver um rosto, nem que fosse como antídoto à obsessão sem fundo e sem fim que me impedia de começar escrever o meu suposto romance (o que eu havia dito a muita gente), que me deixava paralisado, com o medo que a realidade seria sempre muito mais terrível e surpreendente do que eu podia imaginar e que só se revelaria quando fosse tarde, com a pesquisa terminada e o livro publicado. [...] Eu precisava de um rosto real, de alguém que me tivesse alguma relação, ainda que remota, com os personagens da história e que, mesmo sem me revelar nada do que eu já não soubesse, pudesse servir como uma ancora que me impedisse de continuar à deriva naquele limbo, alguém que me acordasse daquele poço de suposições não comprovadas. (CARVALHO, 2006: 141).

Como se nota no enxerto acima, inicialmente, não foi o desejo de escrever o romance que conduziu à pesquisa. $\mathrm{O}$ que, então, motivou o narrador a ir tão longe? Apesar de nada haver a esse respeito ao longo da narrativa, podemos supor que, a partir do momento em que é confundido com Buell Quain, o jornalista passou a encará-lo como uma espécie de duplo. Sua identidade, desde aquele momento, ficou sombreada pela identidade de um Outro desconhecido. Nesse caso, é possível que a investigação da 
vida e morte do antropólogo tenha sido movida pelo desejo do jornalista de descobrir algo sobre si mesmo.

Ter a identidade sob a sombra de um Outro não era novidade para o narrador. $\mathrm{Na}$ infância, para obter vantagens, seu pai costumava apresentá-lo como bisneto do Marechal Rondon. Assim, o sertanista brasileiro surge como uma primeira figura a sombrear sua identidade. Na vida adulta, especialmente durante a jornada em busca de resposta para o suicídio de Buell, o jornalista nega-se a aceitar certas identificações, optando por manter sua alteridade. Primeiro, diferente do bisavô, não adota uma atitude paternalista em relação aos indígenas. Depois, recusa-se a ser confundido com antropólogo e, definitivamente, nega-se a converter-se em um índio.

Essas negações ficam bastante evidente durante a estadia do narrador na última aldeia indígena pesquisada por Quain. A visita do jornalista à tribo é marcada por choques culturais, especialmente no que tange aos ritos de passagens. $\mathrm{O}$ narrador recusa-se a participar de cerimônias que o tornariam definitivamente membro da aldeia, demarcando, assim, sua alteridade em relação ao grupo de índios que o recepcionou.

As considerações de Van Gennep (2011) sobre os ritos de agregação do estrangeiro nos ajudam a entender melhor esse ponto da narrativa de Nove Noites. De acordo com o referido pesquisador, uma série de rituais são progressivamente executadas durante a presença de um forasteiro na aldeia, a fim de aproximá-lo do grupo. Vários dos ritos de passagens citados por Gennep são aludidos no romance de Bernardo Carvalho. Daremos destaque aqui, especialmente, à troca de presentes, à comensalidade, à pintura corporal, à escolha de uma família e ao batismo.

A troca de presentes, conforme Van Gennep (2011: 44) "possui ação coercitiva. Aceitar um presente de alguém significa ligar-se a tal pessoa". Essa ligação é recusada na infância pelo narrador, quando esteve com o pai no Xingu:

Quando fomos embora no dia seguinte, ele saiu de cuecas e relógio. Os índios ficaram com o resto. Não deixei nada meu. Estava farto daquela gente, não queria dar nada de presente a ninguém, embora tenha saído de mãos cheias, depois de receber os indefectíveis tacapes, arcos, flechas e cocares em homenagem ao meu bisavô, graças mais uma vez a intervenção do meu pai (CARVALHO, 2006: 141). 
Durante a estada do narrador na aldeia pesquisada por Quain, a recusa em participar do rito da troca dos presentes já não pode ser mantida. O narrador encontravase em um mundo que não é o seu, portanto, dependia dos índios para tudo. Além disso, queria obter algumas informações. Para evitar constrangimentos e os inumeráveis pedidos dos índios, ele disse, logo de início, que tudo que trouxera na mochila ficaria para eles quando fosse embora. Ser simpático era agora uma obrigação.

Essa tentativa de ser amistoso também se torna evidente através da prática da comensalidade. Compartilhar a comida também constitui, segundo Gennep, um meio de agregação. Para o narrador-jornalista de Nove Noites, os ritos vinculados à comensalidade certamente foi um dos mais difíceis. Ele precisou elogiar a comida, mesmo considerando-a intragável. Não obstante, teve de compartilhar as barras de cereal que havia levado para aldeia, já prevendo que não se adaptaria aos hábitos alimentares indígenas.

Nota-se que embora contrariado, o narrador acaba cedendo a alguns rituais indígenas. A prática da pintura corporal é um deles. Após deixar-se pintar, o narrador nota que a tribo começa a tratá-lo com maior deferência. Diz ele "Sem que eu tivesse noção, ceder ao jenipapo tinha sido como fazer um primeiro gesto de respeito e amizade em relação aos índios" (CARVALHO, 2006: 91).

Por outro lado, aceitar as pinturas conduziu também ao rito da escolha da família. Este serviria para escolher o clã do narrador e apresentá-lo às mulheres com quem ele poderia ou não manter relações sexuais. A narração desse momento é marcada pelo contragosto do narrador, expresso em frases como "Tudo o que eu queria era não ter que participar de nada" e "Eu não queria ser apresentado a ninguém" (CARVALHO, 2006: 92). Por fim, ele se nega a seguir com o ritual:

Nada aconteceu comigo naquela noite, mas prevendo a iminência do batizado que me preparavam (afinal, para que teriam me apresentado a minha 'família' se não fosse para me dar um nome em seguida?), procurei o antropólogo e deixei bem claro que não estava disposto a ser coberto de penas ou ter o cabelo cortado à moda Krahô e que lutaria até o final para me defender (CARVALHO, 2006: 92).

No dia seguinte, o narrador descobre que, para não decepcionar os Krahô, o antropólogo que o conduziu até a tribo teve de substituí-lo no batismo. Afinal, para os 
índios, o rito de agregação é muito importante. Trata-se de uma forma de garantir a benevolência e a ajuda de pessoas que possam ampará-los fora da aldeia. Conforme explica o narrador:

Assim como os índios o adotam quando o recebem na aldeia, eles esperam que você também os adote quando vão à cidade. [...] Precisam de aliança no mundo dos brancos, um mundo que eles tentam entender com esforço e em geral em vão. O problema é que a relação mútua já nasce desequilibrada, uma vez que a frequência com que os Krahô vêm aos brancos é muito maior do que a frequência com que os brancos vão aos Krahô. Uma vez que o mundo é dos brancos. Há neles uma carência irreparável. Não querem ser esquecidos. Agarram-se como podem a todos os que passam pela aldeia, como se os visitantes fossem os pais há muito desaparecidos (CARVALHO, 2006: 97).

A relação entre o narrador e os índios Krahô foi, portanto, mediada pelo interesse recíproco. Os índios precisam de proteção fora da aldeia. O narrador precisava de amparo na aldeia e de informações que supostamente os índios teriam. Assim, a identificação entre eles é fingida, até que o narrador decide romper com as máscaras e manter a alteridade, recusando-se a participar do batismo indígena.

Fora da aldeia, a pesquisa do narrador também teve que ser conduzida através da ficcionalização do Eu. Nesse momento, as identidades profissionais são requisitas. As facetas de jornalista e escritor são conjugadas da forma mais conveniente em cada situação. Quando fazia contatos com antropólogos, o narrador dizia que não tinha nenhum interesse acadêmico e que desejava apenas escrever um romance. Para outros grupos de pessoas, buscando despertar o interesse necessário para ser recebido, ele assumia a condição de jornalista.

A fim de juntar as peças que supostamente explicariam o suicídio de Quain, muitas vezes, o narrador inventa estórias, outras vezes conta suas reais intenções. Ao longo da caminhada, descobre que no jogo entre realidade e fingimento está o segredo para atingir seus objetivos. Essa mescla entre o fatual e o fictício se mostra fundamental especialmente quando encontra a chave para o mistério que percorre toda a investigação. Após descobrir a existência de um suposto filho do fotógrafo amigo de Quain, o narrador viaja para os Estados Unidos em busca de conseguir novas informações. Mas, como esse personagem não quis dar entrevista para um jornalista, o 
narrador assumiu uma identidade profissional diferente. Fingiu-se de empacotador e, ao ficar diante do informante desejado, alternou informações verídicas e mentirosas sobre si, já que revelar sua verdadeira identidade poria tudo a perder:

'Você não é americano, é?' Virei-me para ele. Não tinha os olhos claros e aguados do fotógrafo. Eu não conseguia decidir a melhor tática. Podia bancar o agressivo, o espirituoso, rebater a pergunta com uma piada se ao menos tivesse a presença de espírito para isso, a única coisa que eu não podia era ser honesto. Não podia dizer quem eu era, nem de onde vinha. 'Você vem de onde?' E, aí, sem ter tempo de pensar, como se alguém tivesse se adiantado e falasse por mim, em vez de mentir, eu disse a verdade. E ele arregalou os olhos: 'Brasil?'. [...] Perguntou por que eu viera morar em Nova York, e enquanto inventava uma resposta longa, com pausas para fazer reforços na caixa, simulando uma habilidade profissional que obviamente não tinha, percebi que ele era um sujeito sozinho e estava de fato interessado no que eu pudesse dizer. As palavras dali em diante não teriam nenhuma importância. Eu poderia dizer o que quisesse, podia não fazer o menor sentido, só não podia dizer a verdade. Só a verdade poria tudo a perder (CARVALHO, 2006: 143-144).

Enfim, durante todo a investigação, o narrador confronta alteridades e identidades, mesclando os limites entre realidade e ficção. Nota-se assim que, no tocante à ficcionalização de si, a trajetória de Buell Quain e do narrador-jornalista tem aspectos semelhantes. Mas, seja porque viveram em um contexto histórico diferente, seja porque cada um conduziu sua autoficção de forma distinta, o final da trajetória de ambos não coincide.

As divergências no final da história de Buell Quain e do narrador-jornalista engendraram a comparação que traçamos entre eles e os heróis da tragédia e da epopeia. A disparidade entre o percurso de Buell Quain e do narrador-jornalista, ao longo do romance Nove Noites, podem ser melhor compreendidos à luz de uma comparação, efetuada por Roberto Da Matta (1997: 158), acerca das semelhanças entre a jornada do herói épico e as atividades de pesquisa de campo realizadas por antropólogos: "a viagem do etnólogo é como a viagem do herói clássico, partidas em três momentos distintos e independentes: a saída de sua sociedade, o encontro com o outro nos confins 
do seu mundo social e, finalmente o retorno triunfal (como coloca Degérando) a seu próprio grupo, com os seus troféus".

A busca do antropólogo americano caracteriza-se mais por uma fuga de si do que uma procura pelo Outro ou pelo Eu. Como herói trágico, ele não consegue, ou talvez não quisesse, retornar a seu grupo. Já o narrador-jornalista, claramente, procura por um Outro, procura desesperadamente saber quem é o homem com quem foi confundido e porque ele teria se suicidado.

Voltando aos escritos de Da Matta sobre a trajetória do antropólogo, vale lembrar também a aproximação tecida entre a pesquisa de campo e o rito de passagem. De acordo com o pesquisador brasileiro, em dado momento, assim como os nãoiniciados, o antropólogo sai de sua aldeia para passar por um período de aprendizagem. Longe dos laços familiares, ele contará apenas com a ajuda de um padrinho, algo como o auxiliar mágico dos contos de fadas. Ao sair do seio da sua comunidade, o antropólogo, assim como os jovens em processo de iniciação, passará por uma morte simbólica, estará, então, no estágio de liminaridade, deixando de ser um quase-alguém, para se tornar ninguém. Só através do cumprimento de provas, ele poderá ressuscitar e ocupar uma posição social superior, isto é, tornar-se-á definitivamente alguém.

A disparidade entre a trajetória dos dois protagonistas de Nove Noites se torna mais nítida quando comparada com o percurso vivido por antropólogos e jovens em processo de iniciação. Quain sucumbe ao estágio de liminaridade. Ele perece a beira do caminho, quando tentava efetuar a viagem de volta. Assim, a morte simbólica se torna real, Buell passa a ser um não-alguém definitivamente. Já o narrador-jornalista, após realizar algumas viagens, afastando-se de seu grupo de origem, consegue voltar para casa e publicar o livro resultante de suas investigações.

\section{Os cruzamentos entre realidade e ficção em Nove Noites}

Na trama de Nove Noites, a narrativa literária também encontra o seu Outro: a narrativa científica e jornalística. Vale lembrar que, pelo menos desde Aristóteles (1966: p. 50), as diferenças entre narrativa histórica e narrativa literária começam a ser traçadas. O filósofo grego, em sua Poética, já demarcava a diferença entre o ofício de historiador e o de poeta, afirmando que, enquanto o primeiro narra coisas que 
aconteceram, o segundo narra aquilo que poderia acontecer, segundo as leis da verossimilhança e da necessidade.

Já no bojo do positivismo, as diferenças entre literatura e ciência são fortemente reafirmadas. Nesse contexto, disciplinas como história, antropologia, sociologia necessitaram negar qualquer vinculação com a produção ficcional para serem aceitas como forma de conhecimento científico. Assim, as linhas que demarcavam as fronteiras entre realidade e ficção só começam a tornarem-se mais fluidas com o fim do primado da razão iluminista. A partir de então, novas pesquisas nos campos da filosofia, psicologia, antropologia e linguística demonstraram que o ser humano é um ser simbólico. Todas as suas maneiras de relacionar-se ou de construir conhecimento são mediatizados por signos e pelos valores atribuídos a eles. Desse modo, constatou-se que não temos acesso direto àquilo a que chamamos Realidade.

Consequentemente, a pós-modernidade modificou profundamente a concepção que tínhamos do real e reacendeu o debate sobre as diferenças entre literatura e ciências humanas e sociais. A ficção marcava a diferença entre elas, já que compartilhavam o caráter narrativo. A percepção de que as fronteiras estavam cada vez mais tênues tornou a narrativa literária o Outro da narrativa científica e jornalística. Um Outro, por sinal, como todo duplo, bastante incômodo.

Nove Noites, ao tecer um relato permeado pelo factual e pelo fictício, promove a problematização dos limites entre as duas formas do homem narrar e se relacionar com a realidade. O romance apresenta uma narrativa em dois fluxos, que a princípio, parecem ser parecer verdadeiros. De um lado, temos a história contada pelo narrador jornalista, do outro, uma carta-testamento de um personagem denominado de ManuelPerna. À medida que a história se desenvolve, essas duas vertentes narrativas desvelam o quanto de ficcional subjaz nos relatos memorialísticos e científicos. Mas também, nas entrelinhas, descobrem o quanto de real subjaz no campo do literário.

No caso da carta-testamento, o próprio Manoel Perna reafirma mais de uma vez que o que escreve é fruto do que ele se lembra e do que imaginou. Se a memória, como sabemos é atravessada por nossa subjetividade, mais ainda a imaginação. Não obstante, ambas são inscritas sob códigos linguísticos. Assim, a apreensão da verdade só é possível através dos interstícios das camadas que a sobrepõe. Daí o mote repetido pelo redator: "As histórias dependem antes de tudo da confiança de quem as ouve, e da capacidade de interpretá-las" (CARVALHO, 2006: 7). 
Essa necessidade de captar a realidade sobre os interstícios do dito e do não-dito é reafirmada quando Manoel Perna se refere a instabilidade da verdade para o grupo indígena Krahô:

Alguém terá que preveni-lo. Vai entrar numa terra em que a verdade e a mentira não tem mais os sentidos que o trouxeram até aqui. Pergunte aos índios. Qualquer coisa. O que primeiro que lhe passar pela cabeça. E amanhã, ao acordar, faça de novo a mesma pergunta. E depois de amanhã mais uma vez. Sempre a mesma pergunta. E a cada dia receberá uma resposta diferente. A verdade estará perdida entre todas as contradições e os disparates. Quando vier à procura do que o passado enterrou, é preciso saber que estará às portas de uma terra em que a memória não pode ser exumada, pois o segredo, sendo o único bem que se leva para o túmulo, é também a única herança que se deixa aos que ficam, como você e eu, à espera de um sentido, nem que seja pela suposição do mistério, para acabar morrendo de curiosidade. (CARVALHO, 2006: 6).

Se o que entendemos por verdade não tem a mesma importância, nem o mesmo significado para o grupo Krahô, o mesmo se pode dizer dos conceitos de ficção e realidade. Isto se torna mais nítido quando o narrador tenta explicar a um índio que a publicação de um livro, relatando o suicídio de Quain, não trará nenhuma consequência para a aldeia, já que se trata de um romance:

Leusipo perguntou o que eu tinha ido fazer na aldeia. Preferi achar que o tom era amistoso e, no meu paternalismo ingênuo, comecei a lhe explicar o que era um romance. Ele não estava interessado. Queria saber o que eu tinha ido fazer na aldeia. Os velhos estavam preocupados, queriam saber por que eu vinha remexer no passado, e ele não gostava quando os velhos ficavam preocupados. Eu tentava convencê-lo de que não havia motivo para preocupação. Tudo o que eu queria saber já era conhecido. E ele me perguntava: ‘Então, por que você quer saber, se já sabe?'. Tentei lhe explicar que pretendia escrever um livro e mais uma vez o que era um romance, o que era um livro de ficção (e mostrava o que tinha nas mãos), que seria tudo historinha, sem nenhuma consequência na realidade. Ele seguia incrédulo (CARVALHO, 2006: 85). 
Quando o narrador tenta explicar ao índio o que é um romance, esbarra na imprecisão do código linguístico e na variabilidade dos códigos culturais. O extrato de texto acima também é sugestivo porque apresenta o narrador referindo-se a obra dentro dela mesma, produzindo, portanto, o fenômeno denominado de metaficção.

Segundo Gustavo Bernardo (2010: 9), a metaficção é um "fenômeno estético autorreferente, através do qual a ficção duplica-se por dentro, falando de si mesma ou contendo a si mesma". Entre as metáforas apresentadas por Bernardo para dar uma ideia de como a metaficção funciona e quais são suas características, destacamos aqui o uróboro, serpente mítica, que morde a própria cauda, símbolo do autoconhecimento e do recomeço. No caso de Nove Noites, essa característica se evidência nas páginas finais do romance. O jornalista, em sua viagem de retorno dos Estados Unidos para o Brasil, após ter desvendado uma possível solução para o mistério, descobre que está sentado ao lado de um antropólogo que virá para o Brasil estudar os índios. Cria-se, assim, a sensação do eterno retorno.

Outra característica da metaficção, conforme Bernardo, é o anti-ilusionismo. Diferente da obra que tenta disfarçar sua condição ficcional, a obra com metaficção faz questão de expô-la. Isso não significa, entretanto, que ela se propunha a solucionar o mistério. A escrita metaficcional têm consciência da condição ambígua e metafórica do código linguístico. Ela compreende que só temos acesso ao real através da mediação dos discursos. Desse modo, ao invés de resolver o enigma, ela duplica-o.

Em Nove Noites, nunca poderemos saber o que realmente houve com Buell Quain. Antes havia os fatos dispersos. Agora há um relato que tenta organizá-los. Mas nele nada é conclusivo. Ao final da leitura não temos a solução do mistério do suicídio. No máximo, poderemos tirar as nossas próprias conclusões. Sobra-nos a certeza de que a verdade nunca será de todo desvelada. Resta-nos a incerteza do quanto vai de real e de ficcional na construção de cada personagem e de toda a trama narrada. No final das contas temos o prazer de uma grande história, ainda que ela nos mate de curiosidades.

Neste caso, não se trata propriamente da história do antropólogo americano, mas da história da escrita da história. Como observa Salles (2006), algumas obras vão além da tematização do fazer artístico. Elas colocam algum aspecto do ato criador em proeminência ou incorporam dentro do objeto artístico o próprio processo de criação. Este é o caso de Nove Noites.

Ao expor o processo de criação, o pacto de ficção entre leitor e escritor é abalado ainda mais. Ele é substituído pelo pacto de cumplicidade. Através dele, 
conhecemos as dúvidas, angústias, frustrações e alegrias do escritor. Acompanhamos o caminho percorrido e descobrimos a influência dos acasos e das descobertas na mudança do projeto inicial. Ficamos sabendo dos erros e dos acertos, dos avanços e retrocessos. Mediante esse conhecimento, ocorre a dessacralização do objeto artístico. Ele não aparece mais como fruto de uma genialidade transcendental, mas de uma humanidade errante.

A exposição do processo de criação em Nove Noites aparece a partir do relato do narrador-jornalista. Para escrever o romance, ele empreende uma verdadeira pesquisa científica: entrevista pessoas, vasculha arquivos, viaja para o interior do Brasil e para os Estados Unidos. Suas suposições são embasadas nas pistas que conseguiu levantar. As conclusões são confirmadas por documentos, especialmente cartas, cujos trechos aparecem transcritos ao longo do romance.

$\mathrm{O}$ relato do narrador-jornalista muito se assemelha à narrativa científica e jornalística e parece então estar muito mais próximo da verdade, principalmente se comparado à carta-testamento de Manoel Perna. Esta, como descobrimos ao longo do enredo, é completamente ficcional, pois embora Manoel Perna tenha existido, não deixou nenhum documento sobre a morte de Buell. A ironia, é que só é possível estabelecer certos nexos, essenciais para a compreensão do enredo, a partir da narrativa da carta-testamento, que embora fictícia, foi tecida através dos fatos levantados durante a pesquisa. Desse modo, é estabelecido um contraponto entre narrativa literária e narrativa científica, que denuncia o quanto há de imaginação nesta última e o quanto há de realidade na primeira, sem que, entretanto, elas percam suas peculiaridades.

Os interstícios entre factual e fictício no processo de composição de Nove Noites colabora para criação de uma poética e uma poiética mestiça. Cattani (2007), ao diferenciar a mestiçagem do hibridismo e do sincretismo, afirma a sua capacidade em aproximar influências, estilos ou gêneros diferentes de forma a manter a tensão entre eles. Longe de buscar a homogeneidade, a arte mestiça abriga a diversidade e preserva a alteridade dos diversos elementos. Assim, nas palavras de Cattani, a arte mestiça cria uma utopia que é, ao mesmo tempo, crítica e poética:

Crítica, porque se elabora na contracorrente da indiferenciação globalizada, propondo, em oposição a essa, a existência e a aceitação cultural das diferenças socioculturais e artísticas dentro de uma teia rizomática, sem centralidade, sem periferias, sem hierarquias, sem alto nem baixo, sem norte 
nem sul, mas, também, sem fusões nem compromissos. Uma teia na qual os cruzamentos permitem a existência das alteridades e o seu enriquecimento mútuo, com a manutenção, todavia, das diferenças. Poética, porque o lugar da utopia não é apenas o político nem o social, mas, também, o da criação. Criação que enseja um sentido inconcluso, aberto constantemente a um devir que não teme as tensões nascidas dos encontros de diferentes, que gera em si mesmo o lugar das ideias sem lugar (CATTANI, 2007: 32).

Ao aproximar fatos verídicos e ficção, narrativa científica e narrativa literária, Bernardo Carvalho consegue manter a tensão entre elas. Quando o narrador tenta explicar ao índio Krahô que o livro que irá compor não passa de "historinha", reafirmase o caráter da ficção. Entretanto, para escrevê-la, foi necessário pesquisar acontecimentos reais. Por sua vez, os dados, sozinhos, não chegam a formar um todo coerente. Foi necessário criar uma narrativa fictícia para dar-lhe coerência. Enfim, preservando suas alteridades, ficção e história, escrita fictícia e escrita científica enriquecem uma a outra.

\section{A ficcionalização do Eu e do Outro em Nove Noites}

Para contar a história do suicídio de Buell Quain e a pesquisa que realizou sobre ele, Bernardo Carvalho cria dois narradores, Manoel Perna e um narrador sem nome, que se apresenta algumas vezes como jornalista. É sobre a ficcionalização desses dois personagens que queremos fazer algumas considerações. Ambos têm em comum certa ligação com um referente externo.

Manoel Perna existiu de fato, mas a carta que deixou foi escrita por Bernardo Carvalho, como já ressaltamos. Configura-se, assim, um processo em que um Outro é ficcionalizado pelo escritor. Sobre a criação desse personagem disse Bernardo Carvalho, em entrevista concedida a Flávio Moura:

Esse personagem, o Manoel Perna, é uma espécie de desejo do autor de resolver as lacunas que não são resolvidas pela pesquisa. Várias pistas me induziam a certas conclusões, mas eu não tinha certeza. Precisava de um negócio que fechasse. E a única pessoa que podia ter visto era ele. Por isso logo no início percebi que ele seria um dos narradores. No livro ele aparece 
como engenheiro. Na verdade, ele era barbeiro. Mas achei que ia ficar muito inverossímil, ele escrevendo daquele jeito empolado com essa profissão. Foi a única coisa que eu mudei com relação a ele (CARVALHO, 20--, s/n).

Manoel Perna, na condição de amigo de Buell, cumpre então o papel de informar sobre aquilo que o autor imaginou sobre o caso, mas não encontrou evidências suficientes para comprovar. A criação do personagem e do discurso dele aproxima-se da ficcionalização de personagens históricos. Neste caso, a criação não é livre, mas controlada por uma existência real. A imaginação atua como meio de acesso às ideias e pensamentos alheios. O escritor precisa, então, fingir se um Outro.

A criação do narrador-jornalista parte para um viés distinto, embora também esteja ligado a um sujeito real. Trata-se da ficcionalização do Eu. Em vários trechos, as informações sobre a vida do narrador se confundem com a do autor do romance. Além disso, o próprio Bernardo Carvalho confessa que a pesquisa sobre o suicídio de Quain foi, de fato, empreendida por ele. Isso não quer dizer que o narrador seja o autor. O que chamamos de ficcionalização do $\mathrm{Eu}$ difere da autobiografia e do romance autobiográfico e aproxima-se da autoficção. Ao tratar sobre estas três categorias Kingler (2007) menciona que a escrita autoficcional se diferencia por problematizar o narcisismo da sociedade contemporânea, brincar com a noção de sujeito real e jogar com as instâncias das relações extratextuais. Parafraseando Kingler (2007: 62), consideramos a autoficcão como uma narrativa híbrida, ambivalente, na qual a ficção de si tem como referente o autor, mas não como pessoa biográfica, e sim o autor como personagem construído discursivamente. Personagem que se exibe "ao vivo" no momento mesmo de construção do discurso, ao mesmo tempo indagando sobre a subjetividade e posicionando-se de forma crítica perante os seus modos de representação.

Neste caso, percebe-se que há a manutenção da diferença entre o autor como sujeito real e sua autoficção. O próprio termo autoficção implica que a escrita não deseja desvelar a pessoa do escritor. Este não abdica de uma máscara, apenas escolhe a máscara de escritor para fingir sobre si mesmo, reinventar-se a partir do próprio texto.

Refletindo sobre os porquês da presença da autoficção na narrativa latino americana contemporânea, Kingler (2007) chega à conclusão que ela resulta de duas tendências opostas, de um lado, o narcisismo dos sujeitos pós-modernos, que através das novas mídias têm a oportunidade de espetacularizar a si mesmo, e de outro, a 
emergência das minorias que levantam a questão sobre quem fala e quem está autorizado a falar sobre elas. Neste caso, a autoficção tem uma vantagem dupla. Por ser autorreferente, ela fala de si mesmo, o que não recai necessariamente em egocentrismos, pois também fala sobre o Outro. Vale ressaltar a diferença entre as conjunções. Falar pelo Outro quase sempre implica em paternalismo, que ocorre com menos frequência quando se fala sobre o Outro.

Em Nove Noites, as duas possibilidades entram em tensão. No caso do narrador jornalista, isto se torna explícito quando trata sobre os índios. Figueiredo (2010: 124) classifica Bernardo Carvalho como um dos "autores que falam do índio no presente numa visada realista, sem lirismo, sem utopia, sem identificação”. Este modo de abordagem acabou por ser incompreendido por alguns críticos do romance. Perguntado se considera leviano o modo como representou os indígenas, na entrevista aqui já mencionada, Carvalho respondeu:

Eu não considero a abordagem leviana. Deve ser leviana do ponto de vista de um antropólogo. Eu só não quero ser paternalista. Quero tratar o índio de igual para igual. E não tem nenhuma mentira com relação aos índios. Se você for numa aldeia, vai ver a mesma coisa. Fico muito irritado com paternalismo. É curioso você se propor a fazer uma coisa científica, se propor a ter uma liberdade intelectual que, no limite, bate num aspecto moral que impede você de pensar. E eu acho que a relação cotidiana dos antropólogos com os índios costuma ser paternalista. É estranho se portar dessa maneira com relação a um objeto de estudo (CARVALHO, 20--, s/n).

Nesse sentido, há uma crítica implícita àqueles que se propõe a falar pelos índios, assumindo um tom paternalista. Entre falar por e falar a respeito de, o narrador escolhe a segunda opção. Desse modo, sua abordagem não pode ser considerada leviana. Trata-se da exposição de um ponto de vista de um sujeito ficcional, que enfrentou um choque cultural.

No outro extremo, temos a identificação de Manuel Perna para com Buell Quain. Na impossibilidade do antropólogo falar, esse personagem, de certo modo, dá voz a ele, relatando as confidências que ouviu durante nove noites. Entretanto, neste caso, assumir a voz do outro não se configura, necessariamente, como paternalismo. Trata-se de mais um modo de problematizar a instância do referente. A criação de um narrador para falar sobre um Outro implica certo distanciamento que não haveria se o próprio Buell fosse 
requisitado a falar de si mesmo. Nesse sentido, mantém-se a instabilidade entre o que de fato ocorreu e o que é narrado.

\section{Considerações finais}

As relações entre o Eu e o Outro em Nove Noites se constituem entre os liames da realidade e da ficção. Essas duas categorias, portanto, perpassam a construção de identidades e alteridades.

Os personagens partem em busca do Outro a fim de encontrar a si mesmo. Ao longo do percurso, usam máscaras para encobrir fatos sobre sua personalidade que podem impedir o alcance de certos objetivos. Por outro lado, o desejo de manter sua alteridade frente ao diferente se faz presente tanto na trajetória de Buell Quain quanto na do narrador-jornalista. Ambos se recusam a identificar-se completamente com os indígenas.

No que concerne ao processo de criação, observamos que há traços em comum entre a escrita literária e a escrita científica ou jornalística. Entretanto, as oposições, de certo modo, se mantêm.

Quanto a criação dos narradores, percebem-se os riscos que há em falar pelo Outro. O narrador prefere falar sobre os índios a partir de uma experiência empírica. Quanto a Quain, todo o discurso sobre ele é construído a partir dos dados levantados na pesquisa. Manoel Perna, embora assuma o relato sobre o antropólogo, afirma que parte do que narra é fruto de sua imaginação, denunciando a subjetividade da narração memorialística e a impossibilidade de converter-se no Outro.

Nas três instâncias, o factual e o fictício são aproximados, sem que as fronteiras sejam diluídas. Daí a possibilidade de uma revisão crítica sobre elas. A problematização só é plausível quando as alteridades são mantidas. A identidade absoluta torna as questões estéreis. Nas três instâncias, portanto, denuncia-se o mito do antropólogo camaleão, capaz de se adaptar a qualquer cultura estrangeira. Não precisamos nos tornar o Outro para compreendê-lo. É o nosso estranhamento frente ao estrangeiro que nos permite travar um diálogo enriquecedor com ele, através do confronto entre similaridades e diferenças. Não é preciso tornar-se o Outro para respeitá-lo. É preciso respeitá-lo, porque só a partir das alteridades, as identidades se constituem. 


\section{Fontes}

CARVALHO, Bernardo (2006). Nove Noites: romance. São Paulo: Companhia das letras.

\section{Referências bibliográficas}

ARISTÓTELES (1966). Poética. Trad. de Eudoro de Sousa. Porto Alegre: Globo.

BERNARDO, Gustavo (2010). O livro da metaficção. Rio de Janeiro: Tinta Negra Bazar Editorial.

CARVALHO, Bernardo (20--). A trama traiçoeira de "Nove Noites". Trópico. Entrevista concedida a Flávio Moura. Disponível em: <http://www.revistatropico.com. br/tropico/html/textos/1586,1.shl>. Acesso em: 02 jan 2014.

CATTANI, Icleia Borsa (2007). Mestiçagem na arte contemporânea: conceitos e desdobramentos. In: . (Org.). Mestiçagens na arte contemporânea. Porto alegre: Editora da UFRGS.

DAMATTA, Roberto (1997). O trabalho de campo como um rito de passagem. In: Relativizando. Rio de Janeiro: Rocco.

FIGUEIREDO, Eurídice (2010). Representações do indígena na literatura brasileira. In: Representações de etnicidade: perspectivas interamericanas de literatura e cultura. Rio de Janeiro: 7 letras.

FREUD, Sigmund (1980). Totem e Tabu. Rio de Janeiro: Imago. (Obras completas de Sigmund Freud, v. 13).

KINGLER, Diana Irene (2007). Escritas de si, escritas do outro: o retorno do autor e a virada etnográfica. Rio de Janeiro: 7 letras.

SALLES, Cecilia Almeida (2006). Redes da Criação: construção da obra de arte. São Paulo: Horizonte.

VAN GENNEP, Arnould (2011). Os ritos de passagem. Petrópolis: Vozes.

Artigo recebido em 01 de novembro de 2018.

Aprovado em 19 de maio de 2019. 